\title{
Advanced strategies for development of vaccines against human bacterial pathogens
}

\author{
Abhinay Sharma ${ }^{1,3,5} \cdot$ Pooja Sanduja ${ }^{1}$ Aparna Anand ${ }^{5} \cdot$ Pooja Mahajan $^{1} \cdot$ Carlos A. Guzman $^{3} \cdot$ Puja Yadav $^{4}$. \\ Amit Awasthi ${ }^{6} \cdot$ Emanuel Hanski $^{5} \cdot$ Meenakshi Dua ${ }^{2} \cdot$ Atul Kumar Johri $^{1} \mathbb{C}$
}

Received: 19 May 2020 / Accepted: 17 February 2021 / Published online: 22 March 2021

(c) The Author(s) 2021

\begin{abstract}
Infectious diseases are one of the main grounds of death and disabilities in human beings globally. Lack of effective treatment and immunization for many deadly infectious diseases and emerging drug resistance in pathogens underlines the need to either develop new vaccines or sufficiently improve the effectiveness of currently available drugs and vaccines. In this review, we discuss the application of advanced tools like bioinformatics, genomics, proteomics and associated techniques for a rational vaccine design.
\end{abstract}

Keywords Genomics · Human pathogens · Protein microarray · Proteomics · Reverse vaccinology · Vaccine

\section{Introduction}

Emerging literature on the development of drug resistance against pathogens compel us to establish and reinforce the fact that immunization is one of the most effective way to provide long-lasting protection against microbial diseases (Jansen et al. 2018). Despite the availability of various vaccines in the market against different pathogens, there is always a scope in improving already available or preparing

Atul Kumar Johri

akjohri14@yahoo.com

1 School of Life Sciences, Jawaharlal Nehru University, Aruna Asaf Ali Marg, New Delhi 110067, India

2 School of Environmental Sciences, Jawaharlal Nehru University, Aruna Asaf Ali Marg, New Delhi 110067, India

3 Department of Vaccinology, Helmholtz Centre for Infection Research, Inhoffenstraße 7, 38124 Braunschweig, Germany

4 Department of Microbiology, Central University of Haryana, Mahendragarh, Harayana, India

5 Department of Microbiology and Molecular Genetics, The Institute for Medical Research, Israel-Canada (IMRIC), Faculty of Medicine, The Hebrew University of Jerusalem, 9112102 Jerusalem, Israel

6 Translational Health Science and Technology Institute, Faridabad-Gurgaon Expressway, PO box \#04, NCR Biotech Science Cluster, 3rd Milestone, Faridabad, Haryana 121001, India new vaccines against pathogens. For example, "first generation vaccines" [use of inactivated or live attenuated pathogens e.g., Bacillus Calmette Guerin (BCG), plague, pertussis, polio, rabies, and smallpox] were developed long ago while "second generation" vaccines (cell components e.g., polysaccharides or protein antigens of the microorganisms and referred as subunit vaccines) were developed in the last decades. Parallel to these vaccine candidates, use of genetic material (DNA and RNA), genetically modified cells and non-virulent viruses packaged with antigenic DNA or RNA are being explored for vaccine development. After learning from first and second generation of vaccine and evolution of advanced tools in vaccine science, there is enormous scope to improve the development of "third generation" with the help of bioinformatics, genomics, proteomics and other associated techniques. Due to several limitations in conventional approaches, it is essential to adapt well proven and advanced techniques to accelerate vaccine development program bypassing time and energy (Rappuoli 2004; Bagnoli et al. 2011).

Current emphasis is focused on the identification of genes/proteins of pathogens which plays important roles in host-pathogen interaction, bacterial pathogenesis and its survival in host body. The last decades have witnessed a number of technological advances that have the potential to be exploited in the expansion of new vaccines development; therefore, the use of these techniques to develop 
vaccines against important human pathogens is the focus of this article.

\section{Genomics approaches}

Being advantageous over conventional methods, genomics approaches can be used in case of both cultivable as well as non-cultivable microorganisms and are highly efficient to identify all possible antigens expressed universally in different pathogenic strains. Genome-based technologies are helpful to find genuine antigens as well as mimetic antigens that can induce protective immunity against bacterial epitopes (Seib et al. 2012). Gene-expression microarray resolves the problem of complexity of overwhelming data generated by many genomics techniques and offers a useful snapshot of the main cellular events that contribute to the process of microbial pathogenesis, and the identification of key potential vaccine candidate.

Comparative genomics and pan-genome analysis allow a deep comprehensive study of intra and interspecies antigen variability and distribution; and has been described in case of many pathogens like Plasmodium, group B streptococcus (GBS), Neisseria meningitidis serogroup B (MenB) and Streptococcus pyogenes (Vernikos et al. 2015; Swapna and Parkinson 2017; Carlton et al. 2008; Margarit et al. 2009; McCarthy et al. 2018; Lin et al. 2018; Tettelin et al. 2002; Maione et al. 2005). Intra-species analysis helps by sorting common antigens present in all prevalent strains to act as a universal vaccine candidate. The comprehensive methods like multigenome analysis or pan-genome approach have been demonstrated to identify potential vaccine candidates against highly variable pathogens like $S$. pyogenes (Sharma et al. 2013). The development of a GBS vaccine to fight invasive neonatal disease is considered priority by global health authorities (Lin et al. 2018). The genome sequences of GBS serotype type III strain NEM316 and GBS serotype type V strain $2603 \mathrm{~V} / \mathrm{R}$ have been exploited to identify novel and universally accepted vaccine candidates (Glaser et al. 2002; Tettelin et al. 2002, 2005; Maione et al. 2005). Huge intra-species diversity suggests that single genome sequence is not entirely representative and does not offer a complete picture of the genetic variability of a species. Therefore, comparative genomics allows identification of potential antigens on the basis of sequence conservation in different serotypes and strains of a given pathogen (Sharma et al. 2013).

Inter-species analysis guides us to identify and filter out antigens that show high degree of similarity with genes present in the human microbial flora avoiding undesirable cross-reaction of vaccine-elicited antibodies against known benign commensal species. An inter-species comparison of predicted protein sets of $S$. agalactiae, S. pyogenes, and S. pneumoniae has shown that approximately $50 \%$ of proteins are homologous, signifying substantial overlap in potentially relevant pathogenic mechanisms (Tettelin et al. 2002). This information may be exploited to develop a vaccine against multiple species of streptococci. Genomics approaches can identify potential vaccine candidate genes when the pathogen is grown in isolation. Functional aspect of genome dynamics of microorganisms needs to be analysed when they interact with the host. Several functional genomics approaches have been developed to compensate this limitation.

To understand the mechanism of microbial pathogenesis, it is essential to identify the set of genes responsible for the initiation and maintenance of an infection. Initially, there was a lack of suitable techniques for the testing of individual mutants in animal models to understand the function of the genes during infection. The first group of techniques including In vivo expression technology (IVET) and differential fluorescence induction (DFI) has been used to identify bacterial genes by specifically inducing promoters in the infected host (Mahan et al. 1993; Bumann and Valdivia 2007; Adams and Jewett 2018; Roberfroid et al. 2016). In contrast, signature-tagged mutagenesis (STM) was designed to identify genes which are essential for the bacteria to survive in vivo. The technique is based on random mutagenesis of bacteria to identify genes required for in vivo survival where every mutant carries effective molecular signature which can be identified through hybridization (Hensel et al. 1995). The tags from a mixed population of bacterial mutants representing the inoculum and bacteria recovered from infected hosts are detected by PCR, radiolabelling and hybridization analysis. STM is advantageous over other approaches that rely on in vitro grown bacteria and are likely to miss important protective antigens which functions only in vivo (Hensel et al. 1995; Mazurkiewicz et al. 2006; Saenz and Dehio 2005; Ponnusamy et al. 2015). The second group of techniques, including gene expression microarrays, add further advantage to directly measure the gene expression levels on a true genome-wide scale. However, the application of these techniques for analysis of bacterial pathogens during the infection process is still in its early stages. Another method, Reverse Transcriptase Polymerase Chain Reaction (RTPCR) has qualities that bridge with other methods allowing accurate gene expression measurement on a sub-genomic scale. However, it is difficult to study bacterial pathogenesis during the infection process by these techniques.

An anti-genomic approach-combining genome with serological antigen identification technologies have been used to explore the antigenic repertoire of bacterial pathogens (Meinke et al. 2005; Etz et al. 2002; Fritzer et al. 2010; Nafarieh et al. 2017). This integrated approach is useful for antigen validation, as selected clones can be used directly for the generation of specific immune sera without the 
demanding task of high throughput recombinant protein production. These sera can be used in surface protein localization studies and in vitro functional assays. The anti-genome of a particular pathogen, defined by this method, typically consists of approximately 100 antigens; most of them are located on the cell surface or secreted into the external environment. Small-insert genomic libraries are also employed for the in vitro protein selection method termed as 'ribosome display'. It has been employed to identify and characterize the proteins of immunological importance on a genomic scale of the human pathogens (Weichhart et al. 2003; Xiao et al. 2011). In addition, 'Lambda phage display' has been used for domain mapping, antigen discovery and protein interactions to identify potential antigens (Nicastro et al. 2014).

Another antibody-based selection method, in vivo induced antigen technology (IVIAT), has been used to identify antigens in pathogens that are only expressed during human infection (Mahan et al. 1993; Hang et al. 2003; Lombardo et al. 2007). For example, Escherichia coli expressed genomic libraries of Vibrio cholerae were probed by colony blotting, using convalescent human sera. A major challenge in the development of efficient screening methods is the direct selection for protective candidates. For direct selection of protective candidates, expression library immunization technology (ELI) has been successfully applied in case of Mycobacterium tuberculosis. This strategy is based on immunization with plasmid DNA incorporating the whole genome split into small fragments. However, ELI is limited to the study of genes that can be expressed in eukaryotic cells, and it also demands animal models which are suitable for screening purposes (Barry et al. 2004; Talaat and Stemke-Hale 2005; Yang et al. 2017).

\section{Bioinformatics and computational approaches}

The genome sequences are complete inventory of every possible vaccine candidate. Advanced bioinformatics tools can be used to examine the genetic content as well as transcription and translation profiles of any pathogen to unravel more details of its pathogenicity. During last two decades after first bacterial (Haemophilus influenzae) genome sequence was published, 1000s of bacterial and viral genome sequences have been completed (http://www.ebi.ac.uk/genomes/bacte ria.html, http://www.genomesonline.org/cgi-bin/GOLD/bin/ sequencing_status_distribution.cgi, http://www.ncbi.nlm. nih.gov/genomes/GenomesGroup.cgi?taxid=10239\&opt= Virus). The generated genomic information is used to screen the inclusive set of potential proteins encoded by pathogens for the search of vaccine candidates-an approach referred to as reverse vaccinology (Bagnoli et al. 2011).
In silico whole-genome analysis tools accelerate the process of vaccine candidate identification by integrated use of genomics and proteomics study because one can also predict (I) subcellular localization of vaccine candidate proteins, (II) conserved vaccine candidates among different strains and species, (III) topology of surface proteins, (IV) immunogenicity of different epitopes in vaccine candidate proteins, (V) allergic property of proteins and (VI) 3D structure of vaccine candidate proteins to analyse accessibility of immunologically relevant epitopes with the help of already available bioinformatics tools (Gourlay et al. 2017; Alvarez et al. 2018). Successful use of the bioinformatics tools has been evidently reported in case of many bacterial and viral pathogens. For example, due to the heterogeneous distribution of group A streptococcus (GAS) (> 200 serotypes have been reported) in world population and variation of amino acid sequences in proteins across all serotypes, it is very difficult to identify universal vaccine candidates. Therefore, a comprehensive in silico study has been reported (Sharma et al. 2013). The in silico approaches help to predict of functionality of a particular gene which needs to be verified by using proteomics and genomics tools (Table 1).

\section{Proteomics approaches}

To overcome the limitations of genomics approaches like (1) mRNA expression levels does not represent the actual amount of active protein in a cell, (2) gene sequence gives incomplete information about post-translational modifications, and (3) genome information does not describe dynamic cellular processes; proteomics has been used in different ways to identify novel vaccine candidates against several human pathogens (Scoffone et al. 2020; Sousa et al. 2020; Sharma et al. 2013; Rodriguez-Ortega et al. 2006; Nilsson et al. 2018; Zielke et al. 2016; Couto et al. 2016; Lo et al. 2017). The present focus on using proteomics is to identify surface proteins in pathogens that can be targeted as potential vaccine candidates. Authors have analysed and identified microbial surface proteins by using two-dimensional gel electrophoresis (2-DE) coupled with mass spectrometry (MS) and matrix-assisted laser desorption/ionization time-of-flight mass spectrometry (MALDITOF-MS). However, proteins of hydrophobic nature can not be identified efficiently by this method. Subsequently, a twodimensional liquid chromatography coupled with tandem mass-spectrometry (2D-LC-MS/MS) was introduced and found to be particularly useful to identify proteins that are either highly hydrophobic or basic, inadequately expressed, with high molecular weight, and extreme isoelectric points (Bagnoli et al. 2011; Gygi et al. 1999; Chen et al. 2006). Improved protocol was adopted to identify surface proteins (surfome) with minimized contamination of cytoplasmic 
Table 1 Some important available bioinformatics tools used for data mining and prediction of potential vaccine candidates

\begin{tabular}{|c|c|c|c|c|}
\hline Category of tool & Bioinformatics tool & Description & Web address & Reference \\
\hline \multirow[t]{8}{*}{ General tools } & BLAST & $\begin{array}{l}\text { Basic Local Alignment } \\
\text { Search Tool (BLAST) }\end{array}$ & $\begin{array}{l}\text { http://www.ncbi.nlm.nih.gov/ } \\
\text { BLAST/ }\end{array}$ & \\
\hline & PSORTb & $\begin{array}{l}\text { For predicting the location of } \\
\text { proteins in Gram-negative } \\
\text { bacteria (cytoplasm, cyto- } \\
\text { plasmic membrane, peri- } \\
\text { plasm, and outer membrane } \\
\text { or extracellular space) }\end{array}$ & http://www.psort.org/psortb/ & Gardy et al. (2003) \\
\hline & SignalP & $\begin{array}{l}\text { Predicts the presence and } \\
\text { location of signal peptidase } \\
\text { I (SPaseI) cleavage sites } \\
\text { within the N-terminal } 70 \\
\text { amino acids of secreted } \\
\text { proteins }\end{array}$ & $\begin{array}{l}\text { http://www.cbs.dtu.dk/servi } \\
\text { ces/SignalP/ }\end{array}$ & Petersen et al. (2011) \\
\hline & EXPASY & $\begin{array}{l}\text { Analysis of protein sequences } \\
\text { and structures }\end{array}$ & http://www.expasy.org/ & \\
\hline & PDB & $\begin{array}{l}\text { Archive contains structures of } \\
\text { proteins, nucleic acids and } \\
\text { complex assemblies }\end{array}$ & $\begin{array}{l}\text { http://www.pdb.org/pdb/ } \\
\text { home/home.do }\end{array}$ & Bernstein et al. (1977) \\
\hline & PVS & $\begin{array}{l}\text { Web server for protein } \\
\text { sequence variability analy- } \\
\text { sis tuned to facilitate con- } \\
\text { served epitope discovery }\end{array}$ & http://imed.med.ucm.es/PVS/ & Garcia-Boronat et al. (2008) \\
\hline & AlgPred & $\begin{array}{l}\text { Prediction of allergenic } \\
\text { proteins }\end{array}$ & $\begin{array}{l}\text { http://www.imtech.res.in/ } \\
\text { raghava/algpred/ }\end{array}$ & Saha and Raghava (2006) \\
\hline & CTL PRED & $\begin{array}{l}\text { Predicts CTL epitopes that } \\
\text { are crucial in vaccine } \\
\text { design }\end{array}$ & $\begin{array}{l}\text { http://www.imtech.res.in/ } \\
\text { raghava/ctlpred/ }\end{array}$ & Bhasin and Raghava (2004) \\
\hline
\end{tabular}


Table 1 (continued)

\begin{tabular}{|c|c|c|c|c|}
\hline Category of tool & Bioinformatics tool & Description & Web address & Reference \\
\hline \multirow[t]{15}{*}{ T-cell epitope prediction } & EPIMHC & $\begin{array}{l}\text { A curated database of MHC } \\
\text { ligands }\end{array}$ & $\begin{array}{l}\text { http://bio.dfci.harvard.edu/ } \\
\text { epimhc/ }\end{array}$ & Reche and Reinherz (2005) \\
\hline & PEPVAC & $\begin{array}{l}\text { This program fully covers } \\
\text { multi-epitope vaccines } \\
\text { based on genome wide pre- } \\
\text { dictions of MHC-I epitopes }\end{array}$ & $\begin{array}{l}\text { http://immunax.dfci.harvard. } \\
\text { edu/PEPVAC/ }\end{array}$ & Reche and Reinherz (2005) \\
\hline & RANKPEP & $\begin{array}{l}\text { Predicts peptide binders } \\
\text { to MHC-I and MHC-II } \\
\text { molecules }\end{array}$ & $\begin{array}{l}\text { http://bio.dfci.harvard.edu/ } \\
\text { Tools/rankpep.html }\end{array}$ & Reche et al. (2004) \\
\hline & SYFPEITHI & $\begin{array}{l}\text { A database containing thou- } \\
\text { sands of peptide sequences } \\
\text { known to bind class I and II } \\
\text { MHC molecules }\end{array}$ & http://www.syfpeithi.de/ & Rammensee et al. (1999) \\
\hline & BCIPEP & $\begin{array}{l}\text { This database has a collection } \\
\text { of the peptides having a } \\
\text { role in humoral immunity }\end{array}$ & $\begin{array}{l}\text { http://www.imtech.res.in/ } \\
\text { raghava/bcipep/index.html }\end{array}$ & Saha et al. (2005) \\
\hline & IEDB & $\begin{array}{l}\text { This program contains data } \\
\text { related to antibody and } \mathrm{T}- \\
\text { cell epitopes }\end{array}$ & $\begin{array}{l}\text { http://www.immuneepitope. } \\
\text { org/ }\end{array}$ & Vita et al. (2010) \\
\hline & NetCTL 1.2 Server & $\begin{array}{l}\text { Predicts CTL epitopes in } \\
\text { protein sequences }\end{array}$ & $\begin{array}{l}\text { http://www.cbs.dtu.dk/servi } \\
\text { ces/NetCTL/ }\end{array}$ & Larsen et al. (2007) \\
\hline & MHCPred & $\begin{array}{l}\text { MHC I and MHC II binding } \\
\text { prediction }\end{array}$ & $\begin{array}{l}\text { http://www.ddg-pharmfac. } \\
\text { net/mhcpred/MHCPred/ }\end{array}$ & Guan et al. (2003) \\
\hline & NetMHC 3.0 & $\begin{array}{l}\text { Predicts binding of peptides } \\
\text { to a number of different } \\
\text { HLA alleles }\end{array}$ & $\begin{array}{l}\text { http://www.cbs.dtu.dk/servi } \\
\text { ces/NetMHC/ }\end{array}$ & Lundegaard et al. (2008) \\
\hline & DiscoTope 1.2 Server & $\begin{array}{l}\text { Predicts discontinuous } \\
\text { B-cell epitopes from } \\
\text { three-dimensional protein } \\
\text { structures }\end{array}$ & $\begin{array}{l}\text { http://www.cbs.dtu.dk/servi } \\
\text { ces/DiscoTope/ }\end{array}$ & Haste Andersen et al. (2006) \\
\hline & SVMHC & $\begin{array}{l}\text { MHC-I and MHC-II binding } \\
\text { prediction }\end{array}$ & $\begin{array}{l}\text { https://abi.inf.uni-tuebingen. } \\
\text { de/Services/SVMHC }\end{array}$ & Dönnes and Kohlbacher (2006) \\
\hline & EpiJen & MHC I binding prediction & $\begin{array}{l}\text { http://www.ddg-pharmfac. } \\
\text { net/epijen/EpiJen/ }\end{array}$ & Doytchinova et al. (2006) \\
\hline & MHCBN & $\begin{array}{l}\text { A database of MHC binding } \\
\text { and non-binding peptides }\end{array}$ & $\begin{array}{l}\text { http://www.imtech.res.in/ } \\
\text { raghava/mhcbn/ }\end{array}$ & Bhasin et al. (2003) \\
\hline & PREDEPP & $\begin{array}{l}\text { MHC-I epitope prediction } \\
\text { software }\end{array}$ & http://margalit.huji.ac.il/ & Schueler-Furman et al. (2000) \\
\hline & EpiMatrix & $\begin{array}{l}\text { EpiVax's commercial epitope } \\
\text { prediction platform }\end{array}$ & $\begin{array}{l}\text { http://www.epivax.com/ } \\
\text { immunogenicity-scree } \\
\text { ning/epimatrix/ }\end{array}$ & \\
\hline
\end{tabular}


Table 1 (continued)

\begin{tabular}{|c|c|c|c|c|}
\hline Category of tool & Bioinformatics tool & Description & Web address & Reference \\
\hline \multirow[t]{9}{*}{ B-cell epitope tools } & BepiPred 2.0 & $\begin{array}{l}\text { Prediction of linear B-cell } \\
\text { epitopes }\end{array}$ & $\begin{array}{l}\text { http://www.cbs.dtu.dk/servi } \\
\text { ces/BepiPred/ }\end{array}$ & Jespersen et al. (2017) \\
\hline & Bcepred & $\begin{array}{l}\text { Prediction of linear B-cell } \\
\text { epitopes using physico- } \\
\text { chemical properties }\end{array}$ & $\begin{array}{l}\text { http://crdd.osdd.net/raghava/ } \\
\text { bcepred/ }\end{array}$ & Saha and Raghava (2004) \\
\hline & BEST & $\begin{array}{l}\text { Prediction of linear B-cell } \\
\text { epitopes using }\end{array}$ & $\begin{array}{l}\text { http://biomine.cs.vcu.edu/ } \\
\text { datasets/BEST/ }\end{array}$ & Gao et al. (2012) \\
\hline & COBEpro & $\begin{array}{l}\text { Prediction of linear B-cell } \\
\text { epitopes }\end{array}$ & $\begin{array}{l}\text { http://scratch.proteomics.ics. } \\
\text { uci.edu/ }\end{array}$ & Sweredoski and Baldi (2009) \\
\hline & СВTOPE & $\begin{array}{l}\text { Prediction of discontinuous } \\
\text { B-cell epitopes }\end{array}$ & $\begin{array}{l}\text { http://crdd.osdd.net/raghava/ } \\
\text { cbtope/submit.php }\end{array}$ & Ansari and Raghava (2010) \\
\hline & DiscoTope 2.0 & $\begin{array}{l}\text { Prediction of discontinuous } \\
\mathrm{B}-\text { cell epitopes }\end{array}$ & $\begin{array}{l}\text { http://www.cbs.dtu.dk/servi } \\
\text { ces/DiscoTope/ }\end{array}$ & Kringelum et al. (2012) \\
\hline & EpiPred & $\begin{array}{l}\text { Prediction of discontinuous } \\
\text { B-cell epitopes }\end{array}$ & $\begin{array}{l}\text { http://opig.stats.ox.ac.uk/ } \\
\text { webapps/sabdabsabpred/ } \\
\text { EpiPred.php }\end{array}$ & Krawczyk et al. (2014) \\
\hline & Pepitope & $\begin{array}{l}\text { Prediction of linear and dis- } \\
\text { continuous B-cell epitopes } \\
\text { using Pepsurf or Mapitope } \\
\text { algorithm }\end{array}$ & http://pepitope.tau.ac.il/ & Mayrose et al. (2007) \\
\hline & Epitopia & $\begin{array}{l}\text { Prediction of linear and dis- } \\
\text { continuous B-cell epitopes }\end{array}$ & http://epitopia.tau.ac.il/ & Rubinstein et al. (2009) \\
\hline
\end{tabular}

proteins by careful surface digestion of live bacteria with different proteases and mass spectrometry analysis (Rodriguez-Ortega et al. 2006). The same techniques mentioned above have been applied for the analysis of bacterial culture supernatants to identify and analyse bacterial 'secretome' (He et al. 2015; Ravipaty and Reilly 2010). Proteomic studies have been used to study the role of the environment in regulating the pathophysiology of several microorganisms as well as investigate host-microbial interactions (Chen et al. 2016; Agudo et al. 2004; Hardwidge et al. 2004). The application of proteomics provides major opportunities to elucidate disease mechanisms and identify new and globally useful vaccine candidates against microbial infections. A comparative proteomic approach allows the selection of vaccine candidates based on differential expression in virulent versus non-virulent strains, invasive versus less invasive conditions or colonizing versus invasive strains (Shaw et al. 2002).

For large-scale quantitative protein expression, 'Shotgun proteomics' or multidimensional protein identification technology (MudPIT) were devised to identify the proteins expressed in lower abundance which is not possible by 2-D gel electrophoresis ( $\mathrm{Wu}$ and Yates 2003). However, this method was not found suitable for comparative analysis unless Isotope-coded affinity tags (ICATs) were developed for the detection of proteins expressed in abundance as well as at low levels (Gygi et al. 1999; Guina et al. 2003). A further advantage of the ICAT method is that it is based on post-isolation stable isotope labelling of proteins and is therefore not limited to incompatibility of cells and tissues with metabolic labelling. Because ICAT label binding is limited to cysteine residue only, quantification of cysteine deficient proteins (10-20\% in case of bacteria) may not be done. To overcome these troubles, cysteine independent iTRAQ technique was introduced, which uses a set of four isobaric tags comprised of an amine-specific (peptide N-terminus and lysine residues) reactive group, a neutral linker group (28-31 Da mass), and a reporter region (114-117 Da mass) (Snelling et al. 2007). These labels can therefore be used to simultaneously track up to four samples in a single experiment (Choe et al. 2005). Since the tags have the same complete mass, each peak detected in MS represents a single peptide from the combined four samples. MS/MS of each peptide releases the reporter allowing simultaneous quantitation and identification of the peptide. Another method stable isotope labelling with amino acids in cell culture (SILAC) was designed for the quantification of proteins and has been employed on many pathogens to identify vaccine candidates (Ong et al. 2002; Kani 2017; Jang and Kim 2018). This method is similar to those described above, except that cells subjected to different biological conditions are grown in culture in the presence of an essential amino acid 
with a stable isotopic nucleus (e.g., deuterium). Therefore, one sample could be incubated with an unlabelled amino acid and the test sample incubated with a deuterated form. Because the amino acid is essential, the organism requires it for survival, and through several replication cycles all that particular amino acid will be present in the cells proteins in either unlabelled (control) or deuterated (test) form, allowing true quantitation (Ong et al. 2002).

Quantitative comparison of protein expression in a variety of normal, developmental and disease states to understand highly regulated and critically timed cellular processes occurring inside pathogenic bacteria can further be characterized by monitoring the fate of post-translationally modified (PTM) proteins that have a role in pathogenesis and ultimately assist in identifying a suitable vaccine candidate (Macek et al. 2019). The combination of proteomics and serological analysis developed a new technology naming serological proteome analysis (SERPA) that has been useful in the identification of potential vaccine candidates (Klade 2002). These technologies provide valuable insights into the molecular basis of microbial pathogenesis to identify potential vaccine candidates that otherwise might not have been identified using more conventional methods.

Antibody-profiling technologies, such as protein microarrays have been used to estimate antibody responses to hundreds of recombinant antigens and allow the screening of high-density protein arrays for enzyme-substrate, DNA-protein, and protein-protein interactions (Bensi et al. 2012; Emili and Cagney 2000). Furthermore, long-lasting humoral responses against different pathogens can be analysed for diagnostics, understanding pathogenic mechanisms and for the development of vaccines against bacteria, protozoa and viruses (Zhou et al. 2015; Kempsell et al. 2015; Felgner et al. 2009; Vigil et al. 2011; Crompton et al. 2010; DukeCohan et al. 2009; Fernandez et al. 2011). Despite several advantages, some of the limitations with protein microarray are (1) non-recognition of misfolded or multimeric proteins (2) requirement of additional procedures for identification of PTMs or non-protein antigens (3) requirement of expensive fluorescent microarray scanner and sophisticated statistical methods (4) requirement of expensive robotics for printing arrays. Antibody microarray was found to be the most versatile multiplexed immunoassay technology that was used for the exploratory detection and study of protein abundance, function pathways, and potential vaccine /drug targets. Applications of antibody microarray in basic biology and clinical studies have been recently detailed out providing insights into the current trends and future of protein analysis (Chen et al. 2018).

Apart from application of omics-based tools and reverse vaccinology, development of nucleic acid based vaccines have gained attention in last three decades. It combines the positive aspects of live-attenuated vaccines, viral vectors and subunit vaccines. Nucleic acid based vaccines include viral vectors, plasmid DNA (pDNA) and RNA. These vaccines have their own advantages such as (1) induction of both B and T-cell responses; (2) specificity; (3) high stability; (4) economical; (5) no anti-vector immunity. Published research reports show faster progress in nucleic acid based vaccine development against viruses in comparison to bacterial pathogens. Few reports came up showing potential of these vaccines against bacterial pathogens (Maruggi et al. 2017; Budachetri et al. 2020; Silveira et al. 2017).

\section{Current status of vaccine research against major pathogens}

The catastrophic pandemic outbreak of the century by Covid-19 killing 1000s and infected millions in the world warrants global proactive and integrated research and vaccine development program. Other pathogens which causes, AIDS, malaria, tuberculosis, meningitis, dengue are also the major concerns for vaccine research. Most research groups are focused on intra-species conserved surface proteins of bacterial pathogens (GAS, Streptococcus pneumoniae, M. tuberculosis), multi-valent vaccine (Dengue virus and GAS), killed or attenuated whole organisms (Poliovirus, M. tuberculosis, Dengue virus and Helicobacter pylori), and capsular polysaccharide (GBS, Meningococcus and other Grampositive bacterial pathogens) for vaccine development. The biggest challenge for vaccine development is against highly variable and fast evolving human pathogen like coronaviruses, HIV, Influenza, Ebola and Nipah viruses.

We have witnessed the efficiency of powerful genomics, proteomics and bioinformatics approaches for identification of vaccine candidates in last two decades. However, despite the fast and efficient target identification, scientists are still facing the slow and laborious validation steps, use of animal models for the testing of the vaccine candidates and clinical trials. On the other hand, safety and affordability are the two important factors that must be taken under consideration for the development of modern vaccines. In our opinion, new vaccines should have the highest effectiveness in developed and developing countries. The successful use of multi-genome analysis, screening and use of reverse vaccinology approach to develop a universal vaccine against highly variable pathogen like GAS and GBS may open new vistas for the potential development of universal vaccines for other human pathogens.

Open Access This article is licensed under a Creative Commons Attribution 4.0 International License, which permits use, sharing, adaptation, distribution and reproduction in any medium or format, as long as you give appropriate credit to the original author(s) and the source, 
provide a link to the Creative Commons licence, and indicate if changes were made. The images or other third party material in this article are included in the article's Creative Commons licence, unless indicated otherwise in a credit line to the material. If material is not included in the article's Creative Commons licence and your intended use is not permitted by statutory regulation or exceeds the permitted use, you will need to obtain permission directly from the copyright holder. To view a copy of this licence, visit http://creativecommons.org/licenses/by/4.0/.

\section{References}

Adams PP, Jewett MW (2018) Selection of Borrelia burgdorferi promoter sequences active during mammalian infection using in vivo expression technology. Methods Mol Biol 1690:137-154. https://doi.org/10.1007/978-1-4939-7383-5_12

Agudo D, Mendoza MT, Castanares C, Nombela C, Rotger R (2004) A proteomic approach to study Salmonella typhi periplasmic proteins altered by a lack of the DsbA thiol: disulfide isomerase. Proteomics 4(2):355-363. https://doi.org/10.1002/pmic.20030 0554

Alvarez B, Barra C, Nielsen M, Andreatta M (2018) Computational tools for the identification and interpretation of sequence motifs in immunopeptidomes. Proteomics 18(12):e1700252. https://doi. org/10.1002/pmic.201700252

Ansari HR, Raghava GP (2010) Identification of conformational B-cell epitopes in an antigen from its primary sequence. Immunome Res 6:6. https://doi.org/10.1186/1745-7580-6-6

Bagnoli F, Baudner B, Mishra RP, Bartolini E, Fiaschi L, Mariotti P, Nardi-Dei V, Boucher P, Rappuoli R (2011) Designing the next generation of vaccines for global public health. Omics 15:545566. https://doi.org/10.1089/omi.2010.0127

Barry MA, Howell DP, Andersson HA, Chen JL, Singh RA (2004) Expression library immunization to discover and improve vaccine antigens. Immunol Rev 199:68-83. https://doi.org/10. 1111/j.0105-2896.2004.00143.x

Bensi G, Mora M, Tuscano G, Biagini M, Chiarot E, Bombaci M, Capo S, Falugi F, Manetti AG, Donato P, Swennen E, Gallotta M, Garibaldi M, Pinto V, Chiappini N, Musser JM, Janulczyk R, Mariani M, Scarselli M, Telford JL, Grifantini R, Norais N, Margarit I, Grandi G (2012) Multi high-throughput approach for highly selective identification of vaccine candidates: the group a streptococcus case. Mol Cell Proteom 11(6):M111.015693. https://doi.org/10.1074/mcp.M111.015693

Bernstein FC, Koetzle TF, Williams GJ, Meyer EF Jr, Brice MD, Rodgers JR, Kennard O, Shimanouchi T, Tasumi M (1977) The Protein Data Bank. A computer-based archival file for macromolecular structures. J Mol Biol 112(3):535-542. https://doi.org/10. 1016/s0022-2836(77)80200-3

Bhasin M, Raghava GP (2004) Prediction of CTL epitopes using QM, SVM and ANN techniques. Vaccine 22(23-24):3195-3204. https://doi.org/10.1016/j.vaccine.2004.02.005

Bhasin M, Singh H, Raghava GP (2003) MHCBN: a comprehensive database of MHC binding and non-binding peptides. Bioinformatics 19(5):665-666. https://doi.org/10.1093/bioinformatics/ btg055

Budachetri K, Teymournejad O, Lin M, Yan Q, Mestres-Villanueva M, Brock GN, Rikihisa Y (2020) An entry-triggering protein of Ehrlichia is a new vaccine candidate against tick-borne human monocytic ehrlichiosis. mBiol 11(4):e00895-20. https://doi.org/ 10.1128/mBio.00895-20

Bumann D, Valdivia RH (2007) Identification of host-induced pathogen genes by differential fluorescence induction reporter systems. Nat Protoc 2:770-777. https://doi.org/10.1038/nprot.2007.78
Carlton JM, Adams JH, Silva JC, Bidwell SL, Lorenzi H, Caler E, Crabtree J, Angiuoli SV, Merino EF, Amedeo P, Cheng Q, Coulson RM, Crabb BS, Del Portillo HA, Essien K, Feldblyum TV, Fernandez-Becerra C, Gilson PR, Gueye AH, Guo X, Kang'a S, Kooij TW, Korsinczky M, Meyer EV, Nene V, Paulsen I, White O, Ralph SA, Ren Q, Sargeant TJ, Salzberg SL, Stoeckert CJ, Sullivan SA, Yamamoto MM, Hoffman SL, Wortman JR, Gardner MJ, Galinski MR, Barnwell JW, Fraser-Liggett CM (2008) Comparative genomics of the neglected human malaria parasite Plasmodium vivax. Nature 455:757-763. https://doi.org/10.1038/ nature 07327

Chen EI, Hewel J, Felding-Habermann B, Yates JR 3rd (2006) Large scale protein profiling by combination of protein fractionation and multidimensional protein identification technology (MudPIT). Mol Cell Proteom 5:53-56. https://doi.org/10.1074/mcp. T500013-MCP200

Chen S, Thompson KM, Francis MS (2016) Environmental regulation of Yersinia pathophysiology. Front Cell Infect Microbiol 6:25. https://doi.org/10.3389/fcimb.2016.00025

Chen Z, Dodig-Crnković T, Schwenk JM, Tao SC (2018) Current applications of antibody microarrays. Clin Proteom 15(1):1-15

Choe LH, Aggarwal K, Franck Z, Lee KH (2005) A comparison of the consistency of proteome quantitation using two-dimensional electrophoresis and shotgun isobaric tagging in Escherichia coli cells. Electrophoresis 26(12):2437-2449. https://doi.org/10. 1002/elps.200410336

Couto N, Martins J, Lourenco AM, Pomba C, Varela C (2016) A Identification of vaccine candidate antigens of Staphylococcus pseudintermedius by whole proteome characterization and serological proteomic analyses. J Proteom 5:113-124. https://doi.org/ 10.1016/j.jprot.2015.12.017

Crompton PD, Kayala MA, Traore B, Kayentao K, Ongoiba A, Weiss GE, Molina DM, Burk CR, Waisberg M, Jasinskas A, Tan X, Doumbo S, Doumtabe D, Kone Y, Narum DL, Liang X, Doumbo OK, Miller LH, Doolan DL, Baldi P, Felgner PL, Pierce SK (2010) A prospective analysis of the Ab response to Plasmodium falciparum before and after a malaria season by protein microarray. Proc Natl Acad Sci USA 107:6958-6963. https://doi.org/10. 1073/pnas. 1001323107

Doytchinova IA, Guan P, Flower DR (2006) EpiJen: a server for multistep T cell epitope prediction. BMC Bioinform 7:131. https:// doi.org/10.1186/1471-2105-7-131

Duke-Cohan JS, Wollenick K, Witten EA, Seaman MS, Baden LR, Dolin R, Reinherz EL (2009) The heterogeneity of human antibody responses to vaccinia virus revealed through use of focused protein arrays. Vaccine 27:1154-1165. https://doi.org/10.1016/j. vaccine. 2008.12 .035

Dönnes P, Kohlbacher O (2006) SVMHC: a server for prediction of MHC-binding peptides. Nucleic Acids Res 34:194-197. https:// doi.org/10.1093/nar/gkl284

Emili AQ, Cagney G (2000) Large-scale functional analysis using peptide or protein arrays. Nat Biotechnol 18:393-397. https://doi. org/10.1038/74442

Etz H, Minh DB, Henics T, Dryla A, Winkler B, Triska C, Boyd AP, Söllner J, Schmidt W, von Ahsen U, Buschle M, Gill SR, Kolonay J, Khalak H, Fraser CM, von Gabain A, Nagy E, Meinke A (2002) Identification of in vivo expressed vaccine candidate antigens from Staphylococcus aureus. Proc Natl Acad Sci USA 99:6573-6578. https://doi.org/10.1073/pnas.092569199

Felgner PL, Kayala MA, Vigil A, Burk C, Nakajima-Sasaki R, Pablo J, Molina DM, Hirst S, Chew JS, Wang D, Tan G, Duffield M, Yang R, Neel J, Chantratita N, Bancroft G, Lertmemongkolchai G, Davies DH, Baldi P, Peacock S, Titball RW (2009) A Burkholderia pseudomallei protein microarray reveals serodiagnostic and cross-reactive antigens. Proc Natl Acad Sci USA 106:1349913504. https://doi.org/10.1073/pnas.0812080106 
Fernandez S, Cisney ED, Tikhonov AP, Schweitzer B, Putnak RJ, Simmons M, Ulrich RG (2011) Antibody recognition of the dengue virus proteome and implications for development of vaccines. Clin Vaccine Immunol 18:523-532. https://doi.org/10.1128/CVI. 00016-11

Fritzer A, Senn BM, Minh DB, Hanner M, Gelbmann D, Noiges B, Henics T, Schulze K, Guzman CA, Goodacre J, von Gabain A, Nagy E, Meinke AL (2010) Novel conserved group A streptococcal proteins identified by the antigenome technology as vaccine candidates for a non-M protein-based vaccine. Infect Immun 78:4051-4067. https://doi.org/10.1128/IAI.00295-10

Gao J, Faraggi E, Zhou Y, Ruan J, Kurgan L (2012) BEST: improved prediction of B-cell epitopes from antigen sequences. PLoS ONE 7:e40104. https://doi.org/10.1371/journal.pone.0040104

Garcia-Boronat M, Diez-Rivero CM, Reinherz EL, Reche PA (2008) PVS: a web server for protein sequence variability analysis tuned to facilitate conserved epitope discovery. Nucleic Acids Res 36:35-41. https://doi.org/10.1093/nar/gkn211

Gardy JL, Spencer C, Wang K, Ester M, Tusnady GE, Simon I, Hua S, deFays K, Lambert C, Nakai K, Brinkman FS (2003) PSORT-B: improving protein subcellular localization prediction for Gram-negative bacteria. Nucleic Acids Res 31(13):3613-3617. https://doi.org/10.1093/nar/gkg602

Glaser P, Rusniok C, Buchrieser C, Chevalier F, Frangeul L, Msadek T, Zouine M, Couvé E, Lalioui L, Poyart C, Trieu-Cuot P, Kunst F (2002) Genome sequence of Streptococcus agalactiae, a pathogen causing invasive neonatal disease. Mol Microbiol 45(6):1499-1513. https://doi.org/10.1046/j.1365-2958.2002. 03126.x

Gourlay L, Peri C, Bolognesi M, Colombo G (2017) Structure and computation in immunoreagent design: from diagnostics to vaccines. Trends Biotechnol 35:1208-1220. https://doi.org/10. 1016/j.tibtech.2017.06.018

Guan P, Doytchinova IA, Zygouri C, Flower DR (2003) MHCPred: a server for quantitative prediction of peptide-MHC binding. Nucleic Acids Res 31:3621-3624. https://doi.org/10.1093/nar/ gkg510

Guina T, Purvine SO, Yi EC, Eng J, Goodlett DR, Aebersold R, Miller SI (2003) Quantitative proteomic analysis indicates increased synthesis of a quinolone by Pseudomonas aeruginosa isolates from cystic fibrosis airways. Proc Natl Acad Sci USA 100:27712776. https://doi.org/10.1073/pnas.0435846100

Gygi SP, Rist B, Gerber SA, Turecek F, Gelb MH, Aebersold R (1999) Quantitative analysis of complex protein mixtures using isotopecoded affinity tags. Nat Biotechnol 17:994-999. https://doi.org/ $10.1038 / 13690$

Hang L, John M, Asaduzzaman M, Bridges EA, Vanderspurt C, Kirn TJ, Taylor RK, Hillman JD, Progulske-Fox A, Handfield M, Ryan ET, Calderwood SB (2003) Use of in vivo-induced antigen technology (IVIAT) to identify genes uniquely expressed during human infection with Vibrio cholerae. Proc Natl Acad Sci USA 100:8508-8513. https://doi.org/10.1073/pnas.1431769100

Hardwidge PR, Rodriguez-Escudero I, Goode D, Donohoe S, Eng J, Goodlett DR, Aebersold R, Finlay BB (2004) Proteomic analysis of the intestinal epithelial cell response to enteropathogenic Escherichia coli. J Biol Chem 279(19):20127-20136. https://doi. org/10.1074/jbc.M401228200

Haste Andersen P, Nielsen M, Lund O (2006) Prediction of residues in discontinuous B-cell epitopes using protein 3D structures. Protein Sci 15(11):2558-2567. https://doi.org/10.1110/ps.06240 5906

He Y, Wang H, Chen L (2015) Comparative secretomics reveals novel virulence-associated factors of Vibrio parahaemolyticus. Front Microbiol 6:707. https://doi.org/10.3389/fmicb.2015.00707

Hensel M, Shea JE, Gleeson C, Jones MD, Dalton E, Holden DW (1995) Simultaneous identification of bacterial virulence genes by negative selection. Science 269:400-403. https://doi.org/10. 1126/science.7618105

Jang WE, Kim MS (2018) SILAC expands its territory to the pathogenic yeast, Candida albicans. Proteomics 18(5-6):e1700458. https://doi.org/10.1002/pmic.201700458

Jansen KU, Knirsch C, Anderson AS (2018) The role of vaccines in preventing bacterial antimicrobial resistance. Nat Med 24:10-19. https://doi.org/10.1038/nm.4465

Jespersen MC, Peters B, Nielsen M, Marcatili P (2017) BepiPred-2.0: improving sequence-based $\mathrm{B}$-cell epitope prediction using conformational epitopes. Nucleic Acids Res 45:24-29. https://doi. org/10.1093/nar/gkx346

Kani K (2017) Quantitative proteomics using SILAC. Methods Mol Biol 1550:171-184. https://doi.org/10.1007/978-1-4939-67476_13

Kempsell KE, Kidd SP, Lewandowski K, Elmore MJ1, Charlton S, Yeates A, Cuthbertson H, Hallis B, Altmann DM, Rogers M, Wattiau P, Ingram RJ, Brooks T, Vipond R (2015) Whole genome protein microarrays for serum profiling of immunodominant antigens of Bacillus anthracis. Front Microbiol 6:747. https://doi.org/10.3389/fmicb.2015.00747

Klade CS (2002) Proteomics approaches towards antigen discovery and vaccine development. Curr Opin Mol Ther 4:216-223

Krawczyk K, Liu X, Baker T, Shi J, Deane CM (2014) Improving B cell epitope prediction and its application to global antibodyantigen docking. Bioinformatics 30:2288-2294. https://doi.org/ 10.1093/bioinformatics/btu190

Kringelum JV, Lundegaard C, Lund O, Nielsen M (2012) Reliable B cell epitope predictions: impacts of method development and improved benchmarking. PLoS Comput Biol 8:e1002829. https:// doi.org/10.1371/journal.pcbi.1002829

Larsen MV, Lundegaard C, Lamberth K, Buus S, Lund O, Nielsen M (2007) Large-scale validation of methods for cytotoxic T-lymphocyte epitope prediction. BMC Bioinform 8:424. https://doi. org/10.1186/1471-2105-8-424

Lin SM, Zhi Y, Ahn KB, Lim S, Seo HS (2018) Status of group B streptococcal vaccine development. Clin Exp Vaccine Res 7:7681. https://doi.org/10.7774/cevr.2018.7.1.76

Lo AW, Moriel DG, Phan MD, Schulz BL, Kidd TJ, Beatson SA, Schembri MA (2017) 'Omic' approaches to study uropathogenic Escherichia coli virulence. Trends Microbiol 25:729-740. https://doi.org/10.1016/j.tim.2017.04.006

Lombardo MJ, Michalski J, Martinez-Wilson H, Morin C, Hilton T, Osorio CG, Nataro JP, Tacket CO, Camilli A, Kaper JB (2007) An in vivo expression technology screen for Vibrio cholerae genes expressed in human volunteers. Proc Natl Acad Sci USA 104:18229-18234. https://doi.org/10.1073/pnas.0705636104

Lundegaard C, Lamberth K, Harndahl M, Buus S, Lund O, Nielsen M (2008) NetMHC-3.0: accurate web accessible predictions of human, mouse and monkey MHC class I affinities for peptides of length 8-11. Nucleic Acids Res 36:509-512. https://doi.org/ 10.1093/nar/gkn202

Macek B, Forchhammer K, Hardouin J, Weber-Ban E, Grangeasse C, Mijakovic I (2019) Protein post-translational modifications in bacteria. Nat Rev Microbiol 17:651-664. https://doi.org/10.1038/ s41579-019-0243-0

Mahan MJ, Slauch JM, Mekalanos JJ (1993) Selection of bacterial virulence genes that are specifically induced in host tissues. Science 259:686-688. https://doi.org/10.1126/science.8430319

Maione D, Margarit I, Rinaudo CD, Masignani V, Mora M, Scarselli M, Tettelin H, Brettoni C, Iacobini ET, Rosini R, D'Agostino N, Miorin L, Buccato S, Mariani M, Galli G, Nogarotto R, NardiDei V, Vegni F, Fraser C, Mancuso G, Teti G, Madoff LC, Paoletti LC, Rappuoli R, Kasper DL, Telford JL, Grandi G (2005) Identification of a universal Group B streptococcus vaccine by 
multiple genome screen. Science 309:148-150. https://doi.org/ 10.1126/science. 1109869

Margarit I, Rinaudo CD, Galeotti CL, Maione D, Ghezzo C, Buttazzoni E, Rosini R, Runci Y, Mora M, Buccato S, Pagani M, Tresoldi E, Berardi A, Creti R, Baker CJ, Telford JL, Grandi G (2009) Preventing bacterial infections with pilus-based vaccines: the group B streptococcus paradigm. J Infect Dis 199:108-115. https://doi. org/10.1086/595564

Maruggi G, Chiarot E, Giovani C, Buccato S, Bonacci S, Frigimelica E, Margarit I, Geall A, Bensi G, Maione D (2017) Immunogenicity and protective efficacy induced by self-amplifying mRNA vaccines encoding bacterial antigens. Vaccine 35(2):361-368. https://doi.org/10.1016/j.vaccine.2016.11.040

Mayrose I, Penn O, Erez E, Rubinstein ND, Shlomi T, Freund NT, Bublil EM, Ruppin E, Sharan R, Gershoni JM (2007) Pepitope: epitope mapping from affinity-selected peptides. Bioinformatics 23:3244-3246. https://doi.org/10.1093/bioinformatics/btm493

Mazurkiewicz P, Tang CM, Boone C, Holden DW (2006) Signature-tagged mutagenesis: barcoding mutants for genome-wide screens. Nat Rev Genet 7:929-939. https://doi.org/10.1038/nrg19 84

McCarthy PC, Sharyan A, Sheikhi Moghaddam L (2018) Meningococcal vaccines: current status and emerging strategies. Vaccines (Basel) 6(1):12. https://doi.org/10.3390/vaccines6010012

Meinke A, Henics T, Hanner M, Minh DB, Nagy E (2005) Antigenome technology: a novel approach for the selection of bacterial vaccine candidate antigens. Vaccine 23:2035-2041. https://doi.org/ 10.1016/j.vaccine.2005.01.005

Nafarieh T, Bandehpour M, Hashemi A, Taheri S, Yardel V, Jamaati H, Moosavi SM, Mosaffa N (2017) Identification of antigens from nosocomial Acinetobacter baumannii clinical isolates in sera from ICU staff and infected patients using the antigenome technique. World J Microbiol Biotechnol 33(10):189. https://doi. org/10.1007/s11274-017-2355-x

Nicastro J, Sheldon K, Slavcev RA (2014) Bacteriophage lambda display systems: developments and applications. Appl Microbiol Biotechnol 98:2853-2866. https://doi.org/10.1007/ s00253-014-5521-1

Nilsson Bark SK, Ahmad R, Dantzler K, Lukens AK, De Niz M, Szucs MJ, Jin X, Cotton J, Hoffmann D, Bric-Furlong E, Oomen R, Parrington M, Milner D, Neafsey DE, Carr SA, Wirth DF, Marti M (2018) Quantitative proteomic profiling reveals novel Plasmodium falciparum surface antigens and possible vaccine candidates. Mol Cell Proteom 17:43-60. https://doi.org/10.1074/mcp. RA117.000076

Ong SE, Blagoev B, Kratchmarova I, Kristensen DB, Steen H, Pandey A, Mann M (2002) Stable isotope labeling by amino acids in cell culture, SILAC, as a simple and accurate approach to expression proteomics. Mol Cell Proteom 1:376-386. https://doi.org/ 10.1074/mcp.M200025-MCP200

Petersen TN, Brunak S, von Heijne G, Nielsen H (2011) SignalP 4.0: discriminating signal peptides from transmembrane regions. Nat Methods 8(10):785-786. https://doi.org/10.1038/nmeth.1701

Ponnusamy D, Fitts EC, Sha J, Erova TE, Kozlova EV, Kirtley ML, Tiner BL, Andersson JA, Chopra AK (2015) High-throughput, signature-tagged mutagenic approach to identify novel virulence factors of Yersinia pestis CO92 in a mouse model of infection. Infect Immun 83:2065-2081. https://doi.org/10.1128/IAI. 02913-14

Rammensee H, Bachmann J, Emmerich NP, Bachor OA, Stevanović S (1999) SYFPEITHI: database for MHC ligands and peptide motifs. Immunogenetics 50(3-4):213-219. https://doi.org/10. 1007/s002510050595

Rappuoli R (2004) From Pasteur to genomics: progress and challenges in infectious diseases. Nat Med 10:1177-1185. https://doi.org/ $10.1038 / \mathrm{nm} 1129$

Ravipaty S, Reilly JP (2010) Comprehensive characterization of methicillin-resistant Staphylococcus aureus subsp. aureus COL secretome by two-dimensional liquid chromatography and mass spectrometry. Mol Cell Proteom 9(9):1898-1919. https://doi.org/ 10.1074/mcp.M900494-MCP200

Reche PA, Glutting JP, Zhang H, Reinherz EL (2004) Enhancement to the RANKPEP resource for the prediction of peptide binding to MHC molecules using profiles. Immunogenetics 56(6):405-419. https://doi.org/10.1007/s00251-004-0709-7

Reche PA, Reinherz EL (2005) PEPVAC: a web server for multiepitope vaccine development based on the prediction of supertypic MHC ligands. Nucleic Acids Res 33:138-142. https://doi. org/10.1093/nar/gki357

Roberfroid S, Vanderleyden J, Steenackers H (2016) Gene expression variability in clonal populations: causes and consequences. Crit Rev Microbiol 42(6):969-984. https://doi.org/10.3109/10408 41X.2015.1122571

Rodriguez-Ortega MJ, Norais N, Bensi G, Liberatori S, Capo S, Mora M, Scarselli M, Doro F, Ferrari G, Garaguso I, Maggi T, Neumann A, Covre A, Telford JL, Grandi G (2006) Characterization and identification of vaccine candidate proteins through analysis of the group A Streptococcus surface proteome. Nat Biotechnol 24:191-197. https://doi.org/10.1038/nbt1179

Rubinstein ND, Mayrose I, Martz E, Pupko T (2009) Epitopia: a webserver for predicting B-cell epitopes. BMC Bioinform 10:287. https://doi.org/10.1186/1471-2105-10-287

Saenz HL, Dehio C (2005) Signature-tagged mutagenesis: technical advances in a negative selection method for virulence gene identification. Curr Opin Microbiol 8:612-619. https://doi.org/ 10.1016/j.mib.2005.08.013

Saha S, Raghava GPS (2004) BcePred: prediction of continuous B-cell epitopes in antigenic sequences using physico-chemical properties. In: Nicosia G, Cutello V, Bentley PJ, Timmis J (eds) Artificial Immune Systems. ICARIS 2004, vol 3239. Springer, Berlin, pp 197-204

Saha S, Raghava GPS (2006) AlgPred: prediction of allergenic proteins and mapping of IgE epitopes. Nucleic Acids Res 34:W202-W209

Saha S, Bhasin M, Raghava GP (2005) Bcipep: a database of B-cell epitopes. BMC Genom 6:79. https://doi.org/10.1186/ 1471-2164-6-79

Schueler-Furman O, Altuvia Y, Sette A, Margalit H (2000) Structurebased prediction of binding peptides to MHC class I molecules: application to a broad range of MHC alleles. Protein Sci 9:18381846. https://doi.org/10.1110/ps.9.9.1838

Scoffone VC, Barbieri G, Buroni S, Scarselli M, Pizza M, Rappuoli R, Riccardi G (2020) Vaccines to overcome antibiotic resistance: the challenge of Burkholderia cenocepacia. Trends Microbiol 28(4):315-326. https://doi.org/10.1016/j.tim.2019.12.005

Seib KL, Zhao X, Rappuoli R (2012) Developing vaccines in the era of genomics: a decade of reverse vaccinology. Clin Microbiol Infec 18:109-116. https://doi.org/10.1111/j.1469-0691.2012.03939.x

Sharma A, Arya DK, Sagar V, Bergmann R, Chhatwal GS, Johri AK (2013) Identification of potential universal vaccine candidates against group a streptococcus by using high throughput in silico and proteomics approach. J Proteome Res 12:336-346. https:// doi.org/10.1021/pr3005265 
Shaw AC, Gevaert K, Demol H, Hoorelbeke B, Vandekerckhove J, Larsen MR, Roepstorff P, Holm A, Christiansen G, Birkelund S (2002) Comparative proteome analysis of Chlamydia trachomatis serovar A, D and L2. Proteomics 2(2):164-186

Silveira MM, Oliveira TL, Schuch RA, McBride AJA, Dellagostin OA, Hartwig DD (2017) DNA vaccines against leptospirosis: a literature review. Vaccine 35(42):5559-5567. https://doi.org/10. 1016/j.vaccine.2017.08.067

Snelling WJ, Lin Q, Moore JE, Millar BC, Tosini F, Pozio E, Dooley JS, Lowery CJ (2007) Proteomics analysis and protein expression during sporozoite excystation of Cryptosporidium parvum (Coccidia, Apicomplexa). Mol Cell Proteom 6:346-355. https:// doi.org/10.1074/mcp.M600372-MCP200

Sousa AC, Neiva HP, Izquierdo M, Alves AR, Duarte-Mendes P, Ramalho AG, Marques MC, Marinho DA (2020) Concurrent training intensities: a practical approach for program design. Strength Cond J 42(2):38-44. https://doi.org/10.1519/SSC.00000 00000000520

Swapna LS, Parkinson J (2017) Genomics of apicomplexan parasites. Crit Rev Biochem Mol Biol 52:254-273. https://doi.org/10.1080/ 10409238.2017.1290043

Sweredoski MJ, Baldi P (2009) COBEpro: a novel system for predicting continuous B-cell epitopes. Protein Eng Des Sel 22:113-120. https://doi.org/10.1093/protein/gzn075

Talaat AM, Stemke-Hale K (2005) Expression library immunization: a road map for discovery of vaccines against infectious diseases. Infect Immun 73:7089-7098. https://doi.org/10.1128/IAI.73.11. 7089-7098.2005

Tettelin H, Masignani V, Cieslewicz MJ, Eisen JA, Peterson S, Wessels MR, Paulsen IT, Nelson KE, Margarit I, Read TD, Madoff LC, Wolf AM, Beanan MJ, Brinkac LM, Daugherty SC, DeBoy RT, Durkin AS, Kolonay JF, Madupu R, Lewis MR, Radune D, Fedorova NB, Scanlan D, Khouri H, Mulligan S, Carty HA, Cline RT, Van Aken SE, Gill J, Scarselli M, Mora M, Iacobini ET, Brettoni C, Galli G, Mariani M, Vegni F, Maione D, Rinaudo D, Rappuoli R, Telford JL, Kasper DL, Grandi G, Fraser CM (2002) Complete genome sequence and comparative genomic analysis of an emerging human pathogen, serotype V Streptococcus agalactiae. Proc Natl Acad Sci USA 99:12391-12396. https://doi.org/10.1073/pnas.182380799

Tettelin H, Masignani V, Cieslewicz MJ, Donati C, Medini D, Ward NL, Angiuoli SV, Crabtree J, Jones AL, Durkin AS, DeBoy RT, Davidsen TM, Mora M, Scarselli M, Margarit y Ros I, Peterson JD, Hauser CR, Sundaram JP, Nelson WC, Madupu R, Brinkac LM, Dodson RJ, Rosovitz MJ, Sullivan SA, Daugherty SC, Haft DH, Selengut J, Gwinn ML, Zhou L, Zafar N, Khouri H, Radune D, Dimitrov G, Watkins K, O'Connor KJB, Smith S, Utterback TR, White O, Rubens CE, Grandi G, Madoff LC, Kasper DL, Telford JL, Wessels MR, Rappuoli R, Fraser CM (2005) Genome analysis of multiple pathogenic isolates of Streptococcus agalactiae: implications for the microbial "pan-genome". Proc Nat Acad Sci 102(39):13950-13955

Vernikos G, Medini D, Riley DR, Tettelin H (2015) Ten years of pangenome analyses. Curr Opin Microbiol 23:148-154. https://doi. org/10.1016/j.mib.2014.11.016

Vigil A, Chen C, Jain A, Nakajima-Sasaki R, Jasinskas A, Pablo J, Hendrix LR, Samuel JE, Felgner PL (2011) Profiling the humoral immune response of acute and chronic $\mathrm{Q}$ fever by protein microarray. Mol Cell Proteom. https://doi.org/10.1074/mcp.m110. 006304

Vita R, Zarebski L, Greenbaum JA, Emami H, Hoof I, Salimi N, Damle R, Sette A, Peters B (2010) The immune epitope database 2.0. Nucleic Acids Res 38:854-862. https://doi.org/10.1093/nar/ gkp1004

Weichhart T, Horky M, Sollner J, Gangl S, Henics T, Nagy E, Meinke A, von Gabain A, Fraser CM, Gill SR, Hafner M, von Ahsen U (2003) Functional selection of vaccine candidate peptides from Staphylococcus aureus whole-genome expression libraries in vitro. Infect Immun 71:4633-4641. https://doi.org/10.1128/ IAI.71.8.4633-4641.2003

Wu CC, Yates JR 3rd (2003) The application of mass spectrometry to membrane proteomics. Nat Biotechnol 21:262-267. https://doi. org/10.1038/nbt0303-262

Xiao D, Yin C, Zhang Q, Li JH, Gong PT, Li SH, Zhang GC, Gao YJ, Zhang XC (2011) Selection and identification of a new adhesion protein of Cryptosporidium parvum from a cDNA library by ribosome display. Exp Parasitol 129:183-189. https://doi.org/10. 1016/j.exppara.2011.06.004

Yang X, Li M, Liu J, Ji Y, Li X, Xu L, Yan R, Song X (2017) Identification of immune protective genes of Eimeria maxima through cDNA expression library screening. Parasite Vectors 10(1):85. https://doi.org/10.1186/s13071-017-2029-4

Zhou F, Xu X, Wu S, Cui X, Fan L, Pan W (2015) Protein array identification of protein markers for serodiagnosis of Mycobacterium tuberculosis infection. Sci Rep 5:15349. https://doi.org/10.1038/ srep15349

Zielke RA, Wierzbicki IH, Baarda BI, Gafken PR, Soge OO, Holmes KK, Jerse AE, Unemo M, Sikora AE (2016) Proteomics-driven antigen discovery for development of vaccines against gonorrhea. Mol Cell Proteom 15:2338-2355. https://doi.org/10.1074/mcp. M116.058800

Publisher's note Springer Nature remains neutral with regard to jurisdictional claims in published maps and institutional affiliations. 